\title{
The in Vitro Propagation Techniques for Producing Banana Using Shoot Tip Cultures
}

\author{
Munguatosha Ngomuo', Emerald Mneney², Patrick A. Ndakidemi ${ }^{*}$ \\ ${ }^{1}$ School of Life Sciences, Nelson Mandela African Institute of Science and Technology, Arusha, Tanzania \\ ${ }^{2}$ Mikocheni Agricultural Research Institute, Dar es Salaam, Tanzania \\ Email: ndakidemipa@gmail.com
}

Received 23 March 2014; revised 22 April 2014; accepted 5 May 2014

Copyright (C) 2014 by authors and Scientific Research Publishing Inc.

This work is licensed under the Creative Commons Attribution International License (CC BY).

http://creativecommons.org/licenses/by/4.0/

(c) (i) Open Access

\begin{abstract}
Banana is an important food crop and the second most important fruit crop. Despite the significant commercial value of the crop, the main production constrain is the availability of reliable and safe planting material. The planting materials obtained through conventional methods (suckers) do not meet the increasing demand for planting and they are of poor quality. Tissue culture is the approach which can solve these problems. Micro propagation of the crop is also faced with challenges which need to be addressed in order to improve its production. Some of the problems which hinder the success of the crop include oxidative browning of the wounded tissues and low number of shoots produce per explant. This review highlights the challenges encountered in tissue culture of banana and explores the in vitro propagation techniques by using shoot tip cultures of banana as the possibilities to overcome these problems.
\end{abstract}

\section{Keywords}

Antioxidants, Auxins, Bud Splitting, Cytokinins, Media Composition, Oxidative Browning

\section{Introduction}

Banana (Musa accuminata L.) belongs to the Musaceae family. Banana provides millions of people throughout the tropics and subtropics with staple food and accounts for one of the most widely exported fruits in the world.

Presently, banana is grown in around 150 countries across the world on an area of 4.84 million ha, producing 95.6 million tonnes [1]. It accounts for approximately $22 \%$ of the fresh fruit production and as the second most important fruit crop; Africa accounts for $35 \%$ of the total world production [2]. It is one of the oldest fruits known to mankind and is the most delicious fruit used as subsidiary food. It is used in different ways such as for

*Corresponding author.

How to cite this paper: Ngomuo, M., Mneney, E. and Ndakidemi, P.A. (2014) The in Vitro Propagation Techniques for Producing Banana Using Shoot Tip Cultures. American Journal of Plant Sciences, 5, 1614-1622.

http://dx.doi.org/10.4236/ajps.2014.511175 
table purpose as well as culinary fruit; its leaves and stems are chopped and used as cattle feed. Some species of banana yield fibre, which is used for making ropes. The tip of inflorescence is cooked as a vegetable in some places [3]. The plant is also used for decoration purpose in wedding, festivals and fairs. It is also used as raw material in industries for preparation of banana powder, chips, juices and beer. The juice of banana stem is used in making paper bond, tissue paper etc.

Despite this important use of banana, its production has been decreasing since nineteen seventies. In north western parts of Tanzania in Kagera region, production decreased from $10 \mathrm{t}$ to $4 \mathrm{t}$ per Hectare due to declining soil fertility and emergence of pests and diseases [4]. This is very low production compared with banana production in other parts of the world like India where the production was on an average of $26.7 \mathrm{t}$ per Hectare.

Banana plants are usually propagated by vegetative means by using suckers which grow from lateral buds originating from corms, and suckers are used for production of individual plants. In some instances, complete or separated corms with one or several buds may be used. This process is very slow as the rate of multiplication of suckers through conventional vegetative means has been found to express several negative impacts which include transmission of diseases, low production and poor preservation of original plant genetic material [5]. The non-professional cultivation practices, pest epidemic and viral diseases affect the yield and quality of banana crop [6].

The problem of emerging diseases can be solved by propagating banana through tissue culture [7]. Tissue culture (TC) technology offers mass propagation and clean planting material. In vitro banana production technology is a superior technology over traditional method (Sucker-propagated) of banana production with respect to optimal yield, uniformity, disease-free planting material and true to type plants. Mass multiplication of tissue culture plants could be done in a short time. They are cheaper to transport than conventional suckers and the coupling with virus indexing allows for safe movement, and exchange and conservation of germplasm. In addition, bananas produced using the TC technology are reported to be more vigorous, higher yielding and produce better quality fruits than those produced by conventional means [8].

For commercialization, it is necessary that consistent supplies of good quality bananas are produced to meet the increasing demand. The high rate of multiplication of genetically uniform, pest and disease free planting material can be achieved through tissue culture. Tissue culture approaches would also allow for off-season production of fast growing plants compared with conventionally propagated ones [9].

The in vitro propagation technique for producing banana using shoot tip cultures is a necessary approach in dealing with the problems encountered in tissue culture. These techniques will ensure sustainable production of banana planting materials.

\section{Effects of Media Composition on Growth and Development of Banana Shoot Tips}

The ingredients of plant tissue culture media can be categorized as inorganic salts, organic compounds, complex natural preparations and inert supportive materials [10]. The successes with plant cell and organ cultures have been depended on use of appropriate nutrient media. By providing the necessary chemicals in good combinations and forms, it has been possible to establish cultures from virtually every plant part [10]. Inorganic macronutrient and micronutrient levels used in most plant tissue culture media are based on levels established in the plant tissue culture medium developed by [11] for tobacco tissue culture "MS medium" [12]. As such no single medium can be suggested as being entirely satisfactory for all types of plant tissues and organs [13]. Murashige and Skoog [11], is the most widely used plant culture medium [14]. Several media formulations have been reported for banana shoot tip culture with slight modifications of MS media [15]. Other popular media include B5 [16], SH (Schenk and Hildebrant [17], N6 [18] and Linsmaier and Skoog (LS) [19] media [20] [21]. The MS medium of Murashige and Skoog (1962) is a salt composition that supplies the needed macro and micronutrients. In order to achieve growth and differentiation of cells or tissues, concentrations of inorganic nutrients must be optimized such that the medium meets the requirements of the cells or tissues used [22].

The active factor in the medium is the ions of different types rather than the compounds. One type of ion can be contributed by more than one compound, example $\mathrm{NO}^{3-}$ ions may be contributed by $\mathrm{NH}_{4} \mathrm{NO}_{3}$ as well as $\mathrm{KNO}_{3}$ [13]. Micro propagation of bananas in East Africa with the aim of improved or suitable growth media started recently [23]. However, the success in these efforts is limited. For example, Maerere et al. (2003) successfully managed to (develop a protocol for cv. Bukoba and Uganda) in Tanzania but the field performance of these varieties is not yet evaluated. Optimal growth and morphogenesis of tissues may vary from plant to plant 
based on their nutritional requirements. The source of explants from different parts of same plants may also have different requirements for satisfactory growth [21]. Therefore a need for developing a media with suitable composition for a specific banana cultivar is important in ensuring successful in vitro growth and development of each cultivar.

\section{The Role of Vitamins in Banana Tissue Culture}

Although the basis of all nutrient media is a composition of essential nutrients [24], vitamins are required in trace amounts to serve the catalytic functions in enzyme systems [22]. Some plants can synthesize the essential vitamins for their growth. However when plants are grown in vitro, vitamins may act as limiting factors for cell growth and differentiation [25]. Other studies have confirmed that the vitamins thiamine and nicotinic acid affected cellular division in the pea root meristem [26] [27]. These vitamins worked in combination, i.e. both the presence of thiamine and nicotinic acid promoted the root growth. The four vitamins; myo-inositol, thiamine, nicotinic acid, and pyridoxine are ingredients of Murashige and Skoog (1962) medium and have been used in varying proportions for the culture of tissues of many plant species [28]. The requirements of cells for added vitamins vary according to the nature of the plant and the type of culture [29]. This makes it impossible to conclude that all the vitamins which have been used in a particular experiment were essential or they will work for another experiment.

In banana, vitamins supplementation to the tissue culture media has been scarcely studied and often research workers tend to adopt a "belt and braces" attitude to minor media components, such as vitamins and add unusual supplements just to ensure that there is no missing factor which will limit the success of their experiment. Sometimes complex mixtures of as many as nine or ten vitamins have been employed [29] [30]. Therefore, there is a need to investigate the optimum amount of commonly used vitamins for each banana variety in tissue culture.

\section{The Use of Ant Oxidant and Activated Charcoal in Reducing Oxidative Browning in Banana Tissue Culture}

Banana contains constituents of phenolic enzymes principally polyphenoloxidase enzymes. The polyphenoloxidase enzymes serve as a very important phyto auxine in banana and help to defend the plant against infection from fungi, viruses and bacteria when injured [31]. The constituent of phenols in Musa spp. are principally doparnine, catechin, chlorogenic acid, cinnamic acid, hydroxylbenzoic, resorcinol, progallic acid, salicylic acid, ferulic acid, vanillin coumurin, P-coumaric acid and phenol [32]. Browning reactions and astringency of the fruit are caused by phenolic compounds, and are responsible for high mortality rate (lethal browning) in tissue culture [30]. This process is initiated by browning of the surface of plant tissues due to the oxidation of phenolic compounds resulting in the formation of quinines which are highly reactive and toxic to plant tissue [30] [33].

Apart from being an important group of secondary metabolites, phenolics may act as modulators of plant development by regulating indole acetic acid (IAA) catabolism [34]. They also play effective role in plant growth regulation, cell differentiation and organogenesis [35]. Their concentration is often affected by several internal and external factors example nutrients [36] [37]. Other factors include stress factors such as drought, water, radiation and pathogen infection from injured surfaces, which directly affects the concentrations of phenolics in plants [38].

Activated charcoal is used in control of lethal browning. Its use in micro propagation was first reported by Lu et al. (1990) and it was suggested that charcoal was responsible for adsorption and desorption which controlled the release of nutrients in the production of synthetic seeds [39]. Activated charcoal has a very fine network of pores with large inner surface area on which many substances can be adsorbed [40]. Activated charcoal (AC) is often used in tissue culture to improve cell growth and development. The main benefit is its adsorption of inhibitory substances in culture media. The phenolic oxidation or brown exudates accumulation can be significantly reduced by activated charcoal [41] [42]. However, AC can also adsorb vitamins, cytokinins and auxins, thus changing the ratios of medium components and subsequently influencing plant regeneration [43]. This makes the researchers using AC unaware of the actual quantity available to the plant tissues. Obtaining target levels of adequate free exogenous hormone may be difficult [42].

Control of lethal browning in tissue culture of banana has been reported by different studies. Onuoha et al. [31], reported the use of ant oxidant potassium citrate and citrate (K-C: C) in prevention of browning in plantain culture. As an antioxidant, potassium citrate-citrate reduced browning within two hours before culturing the 
tissues.

Ascorbic acid is also an antioxidant used to control oxidation of phenols [44]-[46]. It is able to scavenge oxygen radicals produced when plant tissue is wounded, thus protecting the cells from the damage resulting from the injury. The detoxification of the free radicals by AA produced through oxidation of the phenolic compounds reduces the extent of browning [33]. In controlling of lethal browning in faba beans, [47] reported that the use of activated charcoal, ascorbic acid, cystene and silver nitrate had a significant effect on the number of shoots and the length of shoots regenerated per explants. [48] reported that addition of cysteine to the growth media reduced explants blackening in banana tissue culture. Understanding the processes contributing to the oxidation of phenols and how these can be minimized when initiating banana tissue culture is critical for successful in vitro culture, not only of banana but also of other crops.

Among the banana varieties susceptible to tissue browning, elimination or reduction of this process is necessary requirement for successful culture establishment. Development of suitable and efficient treatment to minimize tissue browning of these varieties by focusing on suitable antioxidant, the optimum concentration and method of application during explants preparation is of paramount importance.

\section{The Role of Growth Regulators (Auxins and Cytokinin) on Growth and Development of Banana Shoot Tips}

Growth regulators play a key role for developing a specific mode of growth in the cultured cells or tissues, which may be due to accumulation of specific biochemical contents in them. The single or combination of different hormones in the medium causes maintenance of specific and balanced inorganic and organic contents in the growing tissue. This leads the cells or tissues to develop either into shoots/or roots or even death [49].

In tissue culture, plant growth regulators are important media components in determining the development and developmental pathway of the plant cells. Growth regulators are used in different proportions to break dormancy and enhance shoot formation as the apical dormancy is under control of these growth regulators [50]. The cytokinins and auxins are of importance in in vitro culture as the later are concerned with root formation, the former is mainly required in the media for shoot formation and growth of buds [30]. These growth regulators are required in combination in the media as it is always the manipulation and variation of auxins and cytokinins levels that can successfully change the growth behavior of plant cultures [51].

Cytokinins such as benzyl aminopurine (BAP) and kinetin are known to reduce the apical meristem dominance and induce both auxiliary and adventitious shoot formation from meristematic explants in banana [52]. However, the application of higher BAP concentrations inhibits elongation of adventitious meristems and the conversion into complete plants [53].

Auxins and other growth regulator such as gibberellins play important roles in the growth and differentiation of cultured cells and tissues [54] [55]. Auxins such as Naphtalene acetic acid (NAA) have been reported to promote plant rooting in vitro [5] [14].

The use of plant growth regulators (PGRs) in plant nutrient media for in vitro culture depends on plant tissue growth stage and expected end product. Cytokinins play an important role in buds formation in vitro. However buds proliferation in vitro is influenced by apical dominance which is controlled by various growth regulators [56] [57]. Genotype of given plant species determines its buds proliferation in vitro. Apart from the influence of genotypes, shoot proliferation rate and elongation are influenced by cytokinin types and their concentration. Adenine-based cytokinins are used in several Musa spp. for in-vitro propagation [58]. N6-benzylaminopurine (BAP) is the most commonly preferred cytokinin [14]. The others are isopentyladenine (2-ip), zeatin and kinetin [59]. The concentration of exogenous cytokinin appears to be the main factor affecting multiplication.

Many studies have reported the use of auxins and cytokinin in tissue culture. Gubbuk and Pekmzci [58], reported that moderate concentrations of cytokinins increased the shoot proliferation rate, but very high concentrations decreased multiplication and especially depressed shoot elongation [58]. Also they reported higher shoot proliferation and elongation with Thidiazuron (TDZ) than with BAP. However, BAP above $20 \mu \mathrm{M}$ and TDZ over $2 \mu \mathrm{M}$ decreased shoot elongation. The use of TDZ is known to inhibit shoot elongation. In a study conducted by Lee (2004), it was found that TDZ at $0.91 \mu \mathrm{M}$ induced the largest number of shoots, but at higher concentration of TDZ $(9.1 \mu \mathrm{M})$, elongation of shoots was inhibited and clumps of small globular buds appeared at the base of shoots [60].

In a study on effects of auxin/cytokinin combination on shoot proliferation on banana cultivars, [61], reported 
that incorporation of a strong auxin in the media suppressed the shoot proliferation rates of the banana cultivars. On media modified with low cytokinin/auxin ratios, for example 16.8/1.0 and 16.8/1.2 ZN/NAA combinations, the East African Highland banana (AAA-EA) cultivars showed single shoot development and callus induction due to apical dominance resulting from increased level of auxin concentration [61]. In another study, Buah et al. [62], demonstrated that differences existed in the relative strengths of different cytokinin types in inducing shoots. This differential ability of different hormones in inducing shoots in vitro was attributed to factors such as stability, mobility and the rate of conjugation and oxidation of hormones [62]. The concentration and combination of auxins and cytokinins in the nutrient mediums is an important factor which determines successful plant regeneration [22]. Thus for efficient in vitro propagation of banana the establishment of optimum combination of cytokinins and auxins and their interaction in a tissue culture medium for a specific cultivar is necessary.

\section{The Effect of Bud Splitting on Suppression of Apical Dominance and to Induce Multiple Buds Development}

The demand for banana planting material is a major constraint to the expansion of banana production. The long time required for conventional planting material to mature and the prevalence of pests and diseases contributes to these problems.

In the application of bud splitting technique, the banana plantlets of a younger physiological age (single leaf) are longitudinally split to increase the number of explants during tissue culture [5]. This is thought to promote buds proliferation by breaking the apical dominance [63].

It is established that lateral bud development in stems is under the control of the apical bud and that auxin application can sufficiently replace the stem apex in this function in as much as it has also been found that auxin stimulates $\mathrm{C}_{2} \mathrm{H}_{4}$ production in stems [64] [65]. The development of auxiliary meristems is inhibited by apical dominance [66]. These auxiliary meristems are commonly the source of buds formation in nature especially when the apical shoots are damaged or injured [67].

Poor ratooning of plantains results from the strong apical dominance exhibited by the main plant and the competition between suckers [68]. The apical dominance is controlled by growth substances released by the terminal bud, which inhibit growth of lateral buds [69]. Apical dominance is also under the control of several plant growth regulators [56] [57] [63]. Thus, sword suckers of plantains remain small until after flowering of the mother plant because their demand for assimilates (sinks) is too weak under the influence of apical dominance [70].

Bud splitting is not a common practice in banana tissue culture. Some reports on the role of apical dominance in shoot production from explants of banana are conflicting. For example, [71] confirmed that the arrest of apical dominance by removing the shoot tips was essential for the production of multiple shoot initials in cv. Cavendish. However, other studies reported that multiple initials were produced in presence of apical domes in $\mathrm{cv}$. Robusta [72]. [73] reported that removal of apical dome was not essential for multiple shoots formation. On different approach to the same treatment i.e. spliting of the shoot tip; [72] reported a strongly increase in growth rate and shoot proliferation as compared with solid media on subculture of split shoot tips in liquid media. [74] found that temporary immersion of split shoot tips in liquid media for 20 minutes produced the highest multiplication rate after 24 hours [74]. On another study, [75] noticed that longitudinal cuts of buds induced a threefold increase in multiplication. The multiplication rate was also found to depend on the origin of sucker bud, where by lateral buds doubled in size within three weeks while the apical buds reached three times their size.

In general, different cultivars shows variation in the degree of their shoot bud proliferation tendency and the type of multiple budding can be distinguished. This is because the multiple budding appears to be linked to genome configuration of a given cultivar [73] and apical dominance which is under control of PGRs. Thus appropriate concentration of PGRs and bud splitting technique in effort to break dormancy and induce multiple buds development is a necessary study to ensure large numbers of shoots are produced in vitro.

\section{Conclusion}

Banana is a staple food and it accounts for one of the most widely exported fruits in the world. Demand for planting material of banana is very high throughout the tropics and sub tropics. Despite this high demand, availability of safe and reliable planting material is a challenge facing small-scale and large-scale farmers. Propagation of banana through tissue culture is reliable solution to the problems facing farmers. The success in producing 
banana planting material through tissue culture is limited by the technical difficulties associated with our public laboratories among other things. From this background efficient in vitro propagation techniques are necessary to overcome these challenges. Through control of lethal brown, optimum concentration of auxins and cytokinin and arrest of apical dominance through bud splitting technique, these constrains would be solved and greatly contribute to the safe and reliable planting material of banana.

\section{Acknowledgements}

This study was funded by the Nelson Mandela African Institute of Science and Technology through research funds from Commission for Science and Technology (COSTECH) in Tanzania.

\section{References}

[1] Singh, H., Uma, S., Selvarajan, R. and Karihaloo, J. (2011) Micropropagation for production of quality banana planting material in Asia-Pacific. Asia-Pacific Consortium on Agricultural Biotechnology (APCoAB), New Delhi, Vol. 92.

[2] Vuylsteke, D., Swennen, R. and De Langhe, E. (1990) Tissue Culture Technology for the Improvement of African Plantains. Sigatoka Leaf Spot Diseases of Bananas. RA Fullerton and RH Stover. INIBAP, Montpellier, 316-337.

[3] Naduvinamani, R. (2007) Economics of Red Banana Production under Contract Farming in Karnataka. University of Agricultural Sciences, Bangalore.

[4] Gallez, A., Runyoro, G., Mbehoma, C., Van den Houwe, I. and Swennen, R. (2004) Rapid Mass Propagation and Diffusion of New Banana Varieties among Small-Scale Farmers in North Western Tanzania. African Crop Science Journal, 12, 7-17. http://dx.doi.org/10.4314/acsj.v12i1.27657

[5] Hussein, N. (2012) Effects of Nutrient Media Constituents on Growth and Development of Banana (Musa spp.) Shoot Tips Cultured in Vitro. African Journal of Biotechnology, 11, 9001-9006.

[6] Wambugu, F., Njuguna, M., Acharya, S. and Mackey, M. (2008) Socio-Economic Impact of Tissue Culture Banana (Musa Spp.) in Kenya through the Whole Value Chain Approach. International Conference on Banana and Plantain in Africa: Harnessing International Partnerships to Increase Research Impact, 879, 77-86.

[7] Ali, A., Sajid, A., Naveed, N.H., Majid, A., Saleem, A., Khan, U.A., Jafery, F.I. and Naz, S. (2011) Initiation, Proliferation and Development of Micro-Propagation System for Mass Scale Production of Banana through Meristem Culture. African Journal of Biotechnology, 10, 15731-15738. http://dx.doi.org/10.5897/AJB11.2079

[8] Hwan, S.C., Chen, C.L., Lin, J.C. and Lin, H.L. (1976) Cultivation of Banana Using Plantlets from Meristem Culture. HortScience, 19, 231-232.

[9] Eckstein, K. and Robinson, J. (1995) Physiological Responses of Banana (Musa AAA; Cavendish Sub-Group) in the Subtropics. IV. Comparison between Tissue Culture and Conventional Planting Material during the First Months of Development. Journal of Horticultural Science, 70, 549-559.

[10] Huang, L.C. and Murashige, T. (1977) Plant Tissue Culture Media: Major Constitutents, Their Preparation and Some Applications. Methods in Cell Science, 3, 539-548.

[11] Murashige, T. and Skoog, F. (1962) A Revised Medium for Rapid Growth and Bio-Assays with Tobacco Tissue Cultures. Physiologia Plantarum, 15, 473-497. http://dx.doi.org/10.1111/j.1399-3054.1962.tb08052.x

[12] Nassar, A.H. (2004) Effect of Some Copper Compounds on Rhizogenesis of Micropropagated Banana Shoots. International Journal of Agriculture \& Biology, 6, 552-556.

[13] Bhojwani, S.S. and Razdan, M.K. (1986) Plant Tissue Culture: Theory and Practice. Access Online via Elsevier.

[14] Vuylsteke, D.R. (1989) Shoot-Tip Culture for the Propagation, Conservation and Exchange of Musa germplasm.

[15] Browning, G., Ognjanov, V., Passey, A. and James, D. (1987) Multiple Shoot and Root Regeneration from Pear Embryo Cotyledon Explants in Vitro. Journal of Horticultural Science, 62, 305-311.

[16] Gamborg, O.L., Miller, R.A. and Ojima, K. (1968) Nutrient Requirement of Suspension Cultures of Soybean Root Cells. Experimental Cell Research, 50, 151-158. http://dx.doi.org/10.1016/0014-4827(68)90403-5

[17] Schenk, R.U. and Hildebrant, A.C. (1972) Medium and Techniques for Induction and Growth of Monocotyledonous and Dicotyledonous Plant Cell Cultures. Canadian Journal of Botany, 50, 199-204. http://dx.doi.org/10.1139/b72-026

[18] Chu, C.C., Wang, C.C., Sun, C.S., Hsu, C., Yin, K.C., Chu, C.Y. and Bi, F.Y. (1975) Establishment of an Efficient Medium for Another Culture of Rice through Comparative Experiments on the Nitrogen Sources. Scientia Sinica, 18, 659-668.

[19] Lismaier, E.M. and Skoog, F.F. (1975) Organic Growth Factor Requirements of Tobacco Tissue Cultures. Physiologia Plantarum, 18, 100-127. http://dx.doi.org/10.1111/j.1399-3054.1965.tb06874.x 
[20] Hussein, N. (2012) Effects of Nutrient Media Constituents on Growth and Development of Banana (Musa spp.) Shoot Tips Cultured in Vitro. African Journal of Biotechnology, 11, 9001-9006.

[21] Saad, A.I. and Elshahed, A.M. (2012) Plant Tissue Culture Media.

[22] North, J., Ndakidemi, P. and Laubscher, C. (2010) The Potential of Developing an in Vitro Method for Propagating Strelitziaceae. African Journal of Biotechnology, 9, 7583-7588.

[23] Msogoya, T., Maerere, A., Kusolwa, P. and Nsemwa, L. (2006) Field Performance of Improved Banana Cv. Fhia 17 and Fhia 23 in the Eastern Zone of Tanzania. Journal of Agronomy, 5, 533-535. http://dx.doi.org/10.3923/ja.2006.533.535

[24] Ramage, C.M. and Williams, R.R. (2002) Mineral Nutrition and Plant Morphogenesis. In Vitro Cellular \& Developmental Biology—Plant, 38, 116-124. http://dx.doi.org/10.1079/IVP2001269

[25] Torres, K.C. (ed.) (1989) Tissue Culture Techniques for Horticultural Crops. Chapman and Hall, New York, London.

[26] Bonner, J. and Addicott, F. (1937) Cultivation in Vitro of Excised Pea Roots. Botanical Gazette, 99, 144-170.

[27] Ohira, K., Ikeda, M. and Ojima, K. (1976) Thiamine Requirements of Various Plant Cells in Suspension Culture. Plant and Cell Physiology, 17, 583-590.

[28] Murashige, T. (1974) Plant Propagation through Tissue Cultures. Annual Review of Plant Physiology, 25, 135-166. http://dx.doi.org/10.1146/annurev.pp.25.060174.001031

[29] George, E.F., Hall, M.A. and De Klerk, G.J. (2008) The Components of Plant Tissue Culture Media II: Organic Additions, Osmotic and pH Effects, and Support Systems. In: George, E.F., Hall, M.A. and De Klerk, G.J., Eds., Plant Propagation by Tissue Culture, Springer, Berlin, 115-173.

[30] North, J., Ndakidemi, P. and Laubscher, C. (2012) Effects of Antioxidants, Plant Growth Regulators and Wounding on Phenolic Compound Excretion during Micropropagation of Strelitzia Reginae. International Journal of Physical Sciences, 7, 638-646.

[31] Onuoha, I.C., Eze, C.J. and Unamba, C.I. (2011) In Vitro Prevention of Browning in Plantain Culture. OnLine Journal of Biological Sciences, 11, 13-17.

[32] Khalil, M., Moustafa, A. and Naguib, N. (2007) Growth, Phenolic Compounds and Antioxidant Activity of Some Medicinal Plants Grown under Organic Farming Condition. World Journal of Agricultural Sciences, 3, 451-457.

[33] Titov, S., Bhowmik, S.K., Mandal, A., Alam, M.S. and Uddin, S.N. (2006) Control of Phenolic Compound Secretion and Effect of Growth Regulators for Organ Formation from Musa spp. cv. Kanthali Floral Bud Explants. American Journal of Biochemistry and Biotechnology, 2, 97-104. http://dx.doi.org/10.3844/ajbbsp.2006.97.104

[34] Ozyigit, I.I., Kahraman, M.V. and Ercan, O. (2007) Relation between Explant Age, Total Phenols and Regeneration Response in Tissue Cultured Cotton (Gossypium hirsutum L.). African Journal of Biotechnology, 6, 3-8.

[35] Mato, M., Rúa, M. and Ferro, E. (1988) Changes in Levels of Peroxidases and Phenolics during Root Formation in Vitis Cultured in Vitro. Physiologia Plantarum, 72, 84-88. http://dx.doi.org/10.1111/j.1399-3054.1988.tb06626.x

[36] Lux-Endrich, A., Treutter, D. and Feutch, W. (2000) Influence of Nutrients and Carbohydrate Supply on the Phenol Composition of Apple Shoot Cultures. Plant Cell, Tissue and Organ Culture, 60, 15-21.

[37] Zapprometov, M. (1989) The Formation of Phenolic Compounds in Plant Cell and Tissue Cultures and Possibility of Its Regulation. In: Maramorosch, K. and Sato, G.H., Eds., Advances in Cell Culture, Academic Press, Waltham, 240245.

[38] Kefeli, V.I., Kalevitch, M.V. and Borsari, B. (2003) Phenolic Cycle in Plants and Environment. Journal of Molecular Cell Biology, 2, 13-18.

[39] Ganapathi, T.R. and Higgs, N. (1999) Transformation and Regeration of the Banana Cultivar Rasthali (AAB). Proceedings of the International Symposium on the Molecular and Cellular Biology of Bananas, Ithaca, New York, 22-25 March 1999, 13.

[40] Pan, M.J. and van Staden, J. (1998) The Use of Charcoal in in Vitro Culture-A Review. Plant Growth Regulation, 26, 155-163. http://dx.doi.org/10.1023/A:1006119015972

[41] Fridborg, G., Pedersén, M., Landstörm, L.E. and Erikson, T. (1978) The Effect of Activated Charcoal on Tissue Cultures: Adsorption of Metabolites Inhibiting Morphogenesis. Physiologia Plantarum, 43, 104-106. http://dx.doi.org/10.1111/j.1399-3054.1978.tb01575.x

[42] Thomas, T.D. (2008) The Role of Activated Charcoal in Plant Tissue Culture. Biotechnology Advances, 26, 618-631. http://dx.doi.org/10.1016/j.biotechadv.2008.08.003

[43] Teng, W.L. and Ngai, Y.W. (1999) Regeneration of Oxalis triangularis spp. Triangularis from Suspension Cells Cultured in Three Different Systems (Solid, Liquid-Flask and Bioreactor Cultures). Plant Cell Reports, 18, 701-706. http://dx.doi.org/10.1007/s002990050646 
[44] Bhardwaj, L. and Ramawat, K. (1993) Effect of Anti-Oxidants and Adsorbents on Tissue Browning Associated Metabolism in Cocculus Pendulus Callus Cultures. Indian Journal of Experimental Biology, 31, 715-718.

[45] Chawla, H. (2002) Introduction to Plant Biotechnology. Science Publishers.

[46] Abeyaratneb, W. and Lathiff, M. (2002) In-Vitro Propagation of "Rathambala” (Musa AAA) and the Occurrence of Phenotypic Variations in the Pseudostem. Annals of the Sri Lanka Department of Agriculture (LKA), 4, 191-197.

[47] Abdelwahd, R., Hakam, N., Labhilili, M. and Udupa, S.M. (2008) Use of an Adsorbent and Antioxidants to Reduce the Effects of Leached Phenolics in in Vitro Plantlet Regeneration of Faba Bean. African Journal of Biotechnology, 7, 9971002.

[48] Strosse, H., Houwe, I., Panis, B., Jain, S. and Swennen, R. (2004) Banana Cell and Tissue Culture-Review. Banana Improvement: Cellular, Molecular Biology, and Induced Mutations. Proceedings of a Meeting, Leuven, 24-28 September 2001, 1-12.

[49] Dahot, M.U. (2007) Morpho-Physiological Aspects of Micro-Propagating Banana under Different Hormonal Conditions. Asian Journal of Plant Sciences, 6, 496-501. http://dx.doi.org/10.3923/ajps.2007.496.501

[50] Madhulatha, P., Anbalagan, M., Jayachandran, S. and Sakthivel, N. (2004) Influence of Liquid Pulse Treatment with Growth Regulators on in Vitro Propagation of Banana (Musa spp. AAA). Plant Cell, Tissue and Organ Culture, 76, 189-192. http://dx.doi.org/10.1023/B:TICU.0000007291.31439.6c

[51] Gonzales, R.A. (1994) Plant Cell Culture: A Practical Approach. Oxford University Press, Oxford.

[52] Khalid, N. (2011) Effect of Benzylaminopurine (BAP) Pulsing on in Vitro Shoot Multiplication of Musa acuminata (Banana) cv. Berangan. African Journal of Biotechnology, 10, 2446-2450

[53] Buising, C.M., Shoemaker, R.C. and Benbow, R.M. (1994) Early Events of Multiple Bud Formation and Shoot Development in Soybean Embryonic Axes Treated with the Cytokinin, 6-Benzylaminopurine. American Journal of Botany, 81, 1435-1448. http://dx.doi.org/10.2307/2445317

[54] Alexandrova, K., Denchev, P. and Conger, B. (1996) Micropropagation of Switchgrass by Node Culture. Crop Science, 36, 1709-1711. http://dx.doi.org/10.2135/cropsci1996.0011183X003600060049x

[55] Bohidar, S., Thirunavoukkarasu, M. and Rao, T. (2008) Effect of Plant Growth Regulators On In Vitro Micropropagation of 'Garden Rue’ (Ruta graveolens L.). International Journal of Integrative Biology, 3, 36-43.

[56] Wickson, M. and Thimann, K.V. (1958) The Antagonism of Auxin and Kinetin in Apical Dominance. Physiologia Plantarum, 11, 62-74. http://dx.doi.org/10.1111/j.1399-3054.1958.tb08426.x

[57] Cline, M.G. (1994) The Role of Hormones in Apical Dominance. New Approaches to an Old Problem in Plant Development. Physiologia Plantarum, 90, 230-237. http://dx.doi.org/10.1111/j.1399-3054.1994.tb02216.x

[58] Gübbük, H. and Pekmezci, M. (2004) In Vitro Propagation of Some New Banana Types (Musa spp.). Turkish Journal of Agriculture and Forestry, 28, 355-361.

[59] De Langhe, E. and Vuylstek, D. (1985) Feasibility of in Vitro Propagation of Banana and Plantains. Tropical Agriculture (Trinidad), 62, 323-328.

[60] Shirani, S., Mahdavi, F. and Maziah, M. (2009) Morphological Abnormality among Regenerated Shoots of Banana and Plantain (Musa spp.) after in Vitro Multiplication with TDZ and BAP from Excised Shoottips. African Journal of Biotechnology, 8, 5755-5751.

[61] Arinaitwe, G., Rubaihayo, P. and Magambo, M. (1999) Effects of Auxin/Cytokinin Combinations on Shoot Proliferation in Banana Cultivars. African Crop Science Journal, 7, 605-611. http://dx.doi.org/10.4314/acsj.v7i4.27755

[62] Buah, J., Danso, E., Taah, K., Abole, E., Bediako, E., Asiedu, J. and Baidoo, R. (2010) The Effects of Different Concentrations Cytokinins on the in Vitro Multiplication of Plantain (Musa sp.). Biotechnology, 9, 343-347. http://dx.doi.org/10.3923/biotech.2010.343.347

[63] Woolley, D.J. and Wareing, P.F. (1972) The Interaction between Growth Promoters in Apical Dominance. New phytologist, 71, 781-793. http://dx.doi.org/10.1111/j.1469-8137.1972.tb01957.x

[64] Ma, S.S., Shii, C.T. and Wang, S.O. (1978) Regeneration of Banana Plants from Shoot Meristem Tips and Inflorescence Sections in Vitro. 20th International Horticultural Congress, Sydney, August 1978, 15-23.

[65] Kumar, D. and Wareing, P.F. (1972) Factors Controlling Stolon Development in the Potato Plant. New phytologist, 71, 639-648. http://dx.doi.org/10.1111/j.1469-8137.1972.tb01274.x

[66] Razdan, M.K. (2003) Introduction to Plant Tissue Culture. Science Publishers.

[67] Burrows, G. (1989) Developmental Anatomy of Axillary Meristems of Araucaria Cunninghamii Released from Apical Dominance Following Shoot Apex Decapitation in Vitro and in Vivo. Botanical Gazette, 150, 369-377. http://dx.doi.org/10.1086/337782

[68] Swennen, R., Wilson, G. and De Langhe, E. (1984) Preliminary Investigation of the Effects of Gibberellic Acid (GA3) 
on Sucker Development in Plantain (Musa cv. AAB) under Field Conditions. Tropical Agriculture, 61, 253-256.

[69] De Langhe, E., Swennen, R. and Wilson, G. (1983) Aspects hormonaux du rejetonnage des bananiers plantains. Fruits. 38, 318-325.

[70] Ortiz, R. and Vuylsteke, D.R. (1994) Genetics of Apical Dominance in Plantain (Musa spp., AAB Group) and Improvement of Suckering Behavior. Journal of the American Society for Horticultural Science, 119, 1050-1053.

[71] Ma, S.S. and Shii, C.T. (1972) In Vitro Formation of Adventitious Buds in Banana Shoot Apex Following Decapitation. Journal of the Chinese Society for Horticultural Science, 18, 135-142.

[72] Swamy, R.D., Rao, N. and Chacko, E.K. (1983) Tissue-Culture Propagation of Banana. Scientia Horticulturae, 18, 247-252. http://dx.doi.org/10.1016/0304-4238(83)90028-6

[73] Khatri, A., Khan, I.A., Siddiqui, S.H., Ahmad, M. and Siddiqui, K. (1997) In Vitro Culture of Indigenous and Exotic Banana Clones for Maximising Multiplication. Pakistan Journal of Botany, 29, 143-150.

[74] Alvard, D., Cote, F. and Teisson, C. (1993) Comparison of Methods of Liquid Medium Culture for Banana Micropropagation. Plant Cell, Tissue and Organ Culture, 32, 55-60. http://dx.doi.org/10.1007/BF00040116

[75] Mateille, T. and Foncelle, B. (1988) Micropropagation of Musa AAA cv. Poyo in the Ivory Coast. Tropical Agriculture (Trinidad), 65, 325-328. 